\title{
CORRECTION
}

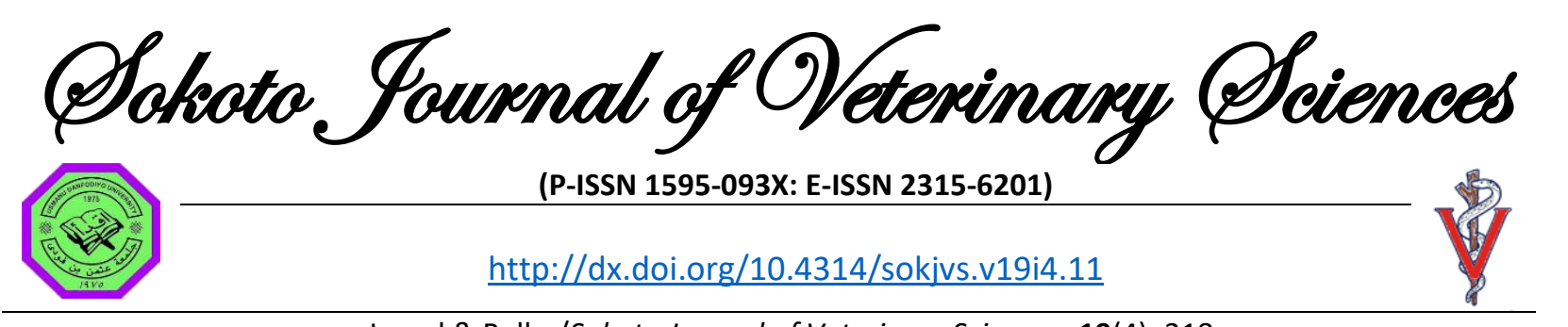

Lawal \& Bello /Sokoto Journal of Veterinary Sciences, 19(4): 218.

\section{Re-Six decades of infectious bursal disease in poultry: The journey so far and challenges ahead}

\author{
N Lawal* \& MB Bello \\ Department of Veterinary Microbiology, Faculty of Veterinary Medicine, Usmanu Danfodiyo University, Sokoto, \\ Nigeria \\ *Correspondence: Tel.: +2348030593816; E-mail: nafiu.lawal@udusok.edu.ng

\begin{tabular}{|c|c|}
\hline $\begin{array}{l}\text { Copyright: } \quad 2021 \\
\text { Lawal \& Bello This is an } \\
\text { open-access article } \\
\text { published under the } \\
\text { terms of the Creative } \\
\text { Commons Attribution }\end{array}$ & $\begin{array}{l}\text { The initial version of the article published in Volume } 19 \\
\text { (September 2021) contained an error in the issue number } \\
\text { written on the first page. The correct issue number is 19(3) } \\
\text { and not } 19(2) \text { as earlier published. }\end{array}$ \\
\hline
\end{tabular}
License which permits unrestricted use, distribution, and reproduction in any medium, provided the original author and source are credited.

Publication History:

Received: 27-11-2020

Revised: 21-02-2021

Accepted: 25-02-2021

Keywords: Infectious bursal disease, Control strategies, Serotypes, Genogroups, Immune-complex vaccines, Virallike particles 